\title{
Dynamic structural parameters verification on the example of theoretical analysis and in situ tests of suspension footbridge
}

\author{
Michał Jukowski ${ }^{1, *}$, Ewa Błazik-Borowa ${ }^{2}$, Jarosław Bęc ${ }^{3}$ and Janusz Bohatkiewicz ${ }^{4}$ \\ 1,2,3,4 Lublin University of Technology, Faculty of Civil Engineering and Architecture, Nadbystrzycka 40, 20-618 Lublin, Poland
}

\begin{abstract}
The 21st century is a period of rapid development of computer technology, which allowed designers to create complex, three-dimensional models of engineering structures. Thanks to these solutions, it is possible to perform complex analyses, for example modal or dynamic ones of cable-stayed or suspension structures. For such objects, verification of the correct work of structural elements takes place in the field of non-linear analysis. The presented paper is an example of a comparative analysis concerning modal and static analysis - Natural Frequency with Nonlinear Material Models and Static Stress with Nonlinear Material Models, carried out in the Autodesk Simulation Multiphysics program with dynamic in situ tests of a suspension footbridge. The main purpose of the research was to evaluate the value of pretension forces in the cables of the load-bearing structure.
\end{abstract}

\section{Introduction}

All cable-stayed and suspension structures must be tested for dynamic properties before they can be put into service. Nowadays technology, both at the design stage, but also at the construction stage, allows verification of the correct structural work under the given load before the construction is completed. This allows you to avoid building disasters. One of the largest ones, being a model example of the impact of dynamic actions (wind action) took place in the north-western United States in 1940 in the city of Tacoma. The suspension bridge was destroyed as a result of the convergence of the frequencies of torsional and flexural vibrations of the bridge span [1].

In the paper, the authors evaluate the main cable tension forces in a suspension footbridge based on the conducted dynamic tests, and determine dynamic parameters such as frequencies of natural vibrations and damping coefficients. The issue is important when assessing the technical condition of existing suspension objects, in the case of lack of the design documentation. The determined dynamic parameters are particularly necessary when analyzing the structural effort caused by dynamic loads.

The technical condition of the object affects the values of the free vibration frequencies and the damping parameters. As shown in [2] in the case of massive structures, the frequency of free vibrations is affected by the corrosion of structural elements such as main beams, crossbars or deck plates. As for suspension or cablestayed footbridges, which are less rigid, the tension in cables (ropes) has a big influence on the dynamic parameters of the structure [3]. During the operation of bridges, due to the rheological phenomena and destruction of ropes among others, the tension in the ropes changes and thus the frequency of free vibrations also changes. The use of dynamic measurements, and in particular in this research, acceleration measurements at the footbridge selected points during free vibrations, is a non-invasive test for the structure and what is the most important, safe for people performing these tests. This confirms the validity and sense of the research undertaken. In Poland there are many old footbridges that need renovation or even reconstruction. An example of this is the footbridge presented in this paper.

\section{Description of the footbridge}

This paper describes the analysis of a footbridge with a suspension structure. Due to its dimensions, mainly the theoretical span, which amounts to as much as $76.50 \mathrm{~m}$, with a width of $3.15 \mathrm{~m}$, this structure seems to be very interesting from the point of view of dynamic research. Due to the lack of technical documentation, the authors carried out a full photographic and structural inventory, with the purpose to present the actual technical condition of the structure including measurements of the main structural elements of the object. In the cross-section, the load-bearing structure consists of three main I-beams 180 , cross-braced with two channel sections 240 joined together with lacing. The main span is suspended to main cables consisting of four ropes each. The cables were made of parallel, coiled wires with a diameter of about $35 \mathrm{~mm}$ each. In addition, hangers with a length from $0.80 \mathrm{~m}$ to $6.10 \mathrm{~m}$ were attached to the cables. The tower leg, about $8.50 \mathrm{~m}$ high, was made of two Isections 450 cross-braced with steel lacing. The deck

Corresponding author: m.jukowski@pollub.pl 
was made of $0.10 \mathrm{~m}$ thick oak boards. Fig. 1 shows a photograph of the analyzed object.

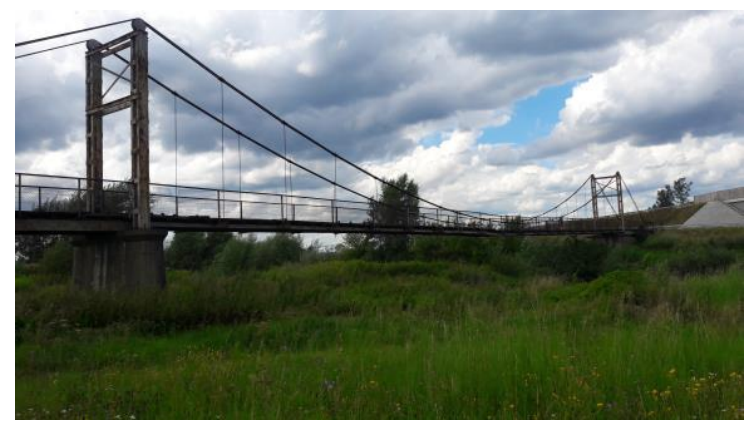

Fig. 1. View of the suspension footbridge.

\section{In situ measurements}

\subsection{Dynamic tests}

In order to verify the dynamic parameters of the analyzed structure, the authors carried out 14 dynamic load tests aimed at identification of the natural frequencies of the structure. Table 1 lists and describes the load cases used.

Table 1. Load cases - dynamic tests.

\begin{tabular}{|c|c|}
\hline LC & Description \\
\hline K1 & $\begin{array}{c}\text { Eight jumps in the middle of the } \\
\text { deck width }(1 / 2 L t)\end{array}$ \\
\hline K2, K3 & $\begin{array}{c}\text { Single strong jump in the middle } \\
\text { of the deck width }\left(1 / 2 L_{t}\right)\end{array}$ \\
\hline K4, K5 & $\begin{array}{c}\text { Single strong jump at the edge of } \\
\text { the deck width }(1 / 2 L t)\end{array}$ \\
\hline K6 & $\begin{array}{c}\text { Three jumps at the edge of the } \\
\text { deck width }(1 / 2 L t)\end{array}$ \\
\hline K8 & $\begin{array}{c}\text { Single strong jump in the middle } \\
\text { of the deck width }(1 / 4 L t)\end{array}$ \\
\hline K10, K11 & $\begin{array}{c}\text { Single strong jump at the edge of } \\
\text { the deck width }(1 / 4 L t)\end{array}$ \\
\hline K12 & Run (jog) along the structure \\
\hline K13 & $\begin{array}{c}\text { Four jumps alternately at both } \\
\text { edges of the deck width }(1 / 2 ~ L t)\end{array}$ \\
\hline K14 & $\begin{array}{c}\text { Ten jumps in the middle of the } \\
\text { deck width }(1 / 2 ~ L t)\end{array}$ \\
\hline
\end{tabular}

The tests were carried out using specialized equipment enabling the recording of the time course of vibration accelerations of the span structure with a frequency of $6000 \mathrm{~Hz}$. The measurement was carried out at four measuring points, i.e. half the theoretical span (PPO_1), one quarter of the span (PPO_2), half the height of the tower (PPO_3) and a quarter of the height of the tower (PPO_4). Three triaxial, piezoelectric accelerometers with sensitivity of $1000 \mathrm{mV} / \mathrm{g}$ and two uniaxial accelerometers with $500 \mathrm{mV} / \mathrm{g}$ sensitivity were used for the tests. In points PPO_1 - PPO_3, triaxial sensors were installed, and two uniaxial sensors were put in PPO 4. Fig. 2 shows a picture of the mounted triaxial sensor.

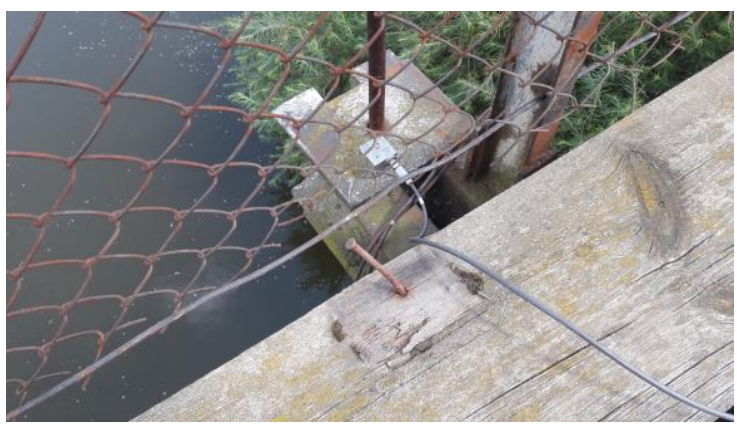

Fig. 2. View of the mounted triaxial sensor.

The analysis of all measured acceleration courses was made. Each of them was processed using the Fast Fourier Transform (FFT), which allowed the identification of the natural frequencies of the structure. Examples of acceleration courses from sensors located at measurement points PPO_1 and PPO_2 for the load cases $\mathrm{K} 1$ and K6 are shown in Fig. 3 and Fig. 4.

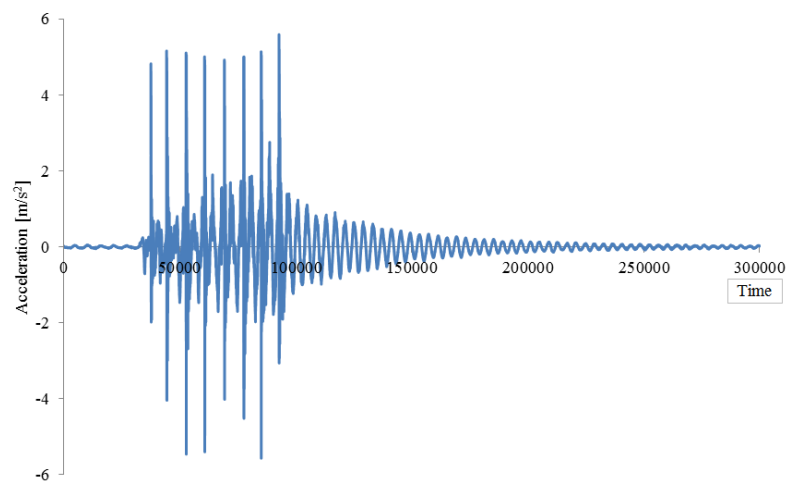

Fig. 3. Course of accelerations at the vertical direction $z$ - point PPO_1, load case K1.

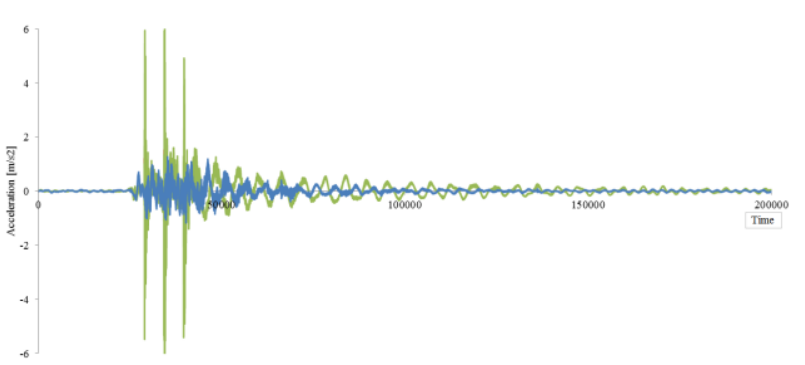

Fig. 4. Courses of accelerations at the vertical direction $z$ : green line - point PPO_1, blue line - point PPO_2, load case K6.

On the basis of FFT analyzes, several dominant natural frequencies of the footbridge were found. From fourteen load tests, two load cases were selected, which were treated as representative ones. These are the load cases $\mathrm{K} 1$ and $\mathrm{K} 6$. In each of the analyzed cases, readings were taken from triaxial sensors located at measurement points PPO_1 and PPO_2. Below, in Figs 5a-5b there are presented the results for the vertical frequency obtained with the load case K1, Figs $6 a-6 b$ show the vertical vibrations from the load case K6, Figs $7 \mathrm{a}-7 \mathrm{~b}$ are for the horizontal direction (perpendicular to the longitudinal axis of the platform) $x$ from the load case K1 and Figs 
$8 \mathrm{a}-8 \mathrm{~b}$ are also for the horizontal direction $x$ from the load case K6.

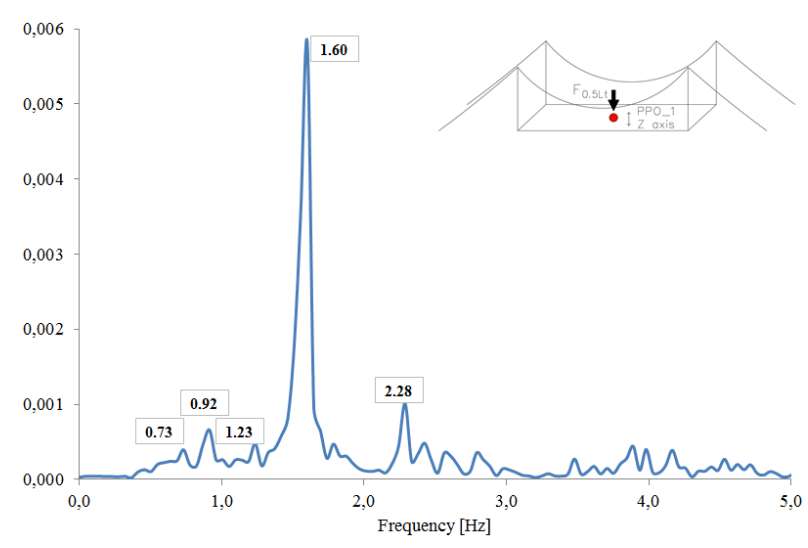

Fig. 5a. Results of the FFT analysis - at the direction $z$, load case K1, point PPO_1.



Fig. 5b. Results of the FFT analysis - at the direction $z$, load case K1, point PPO_2.

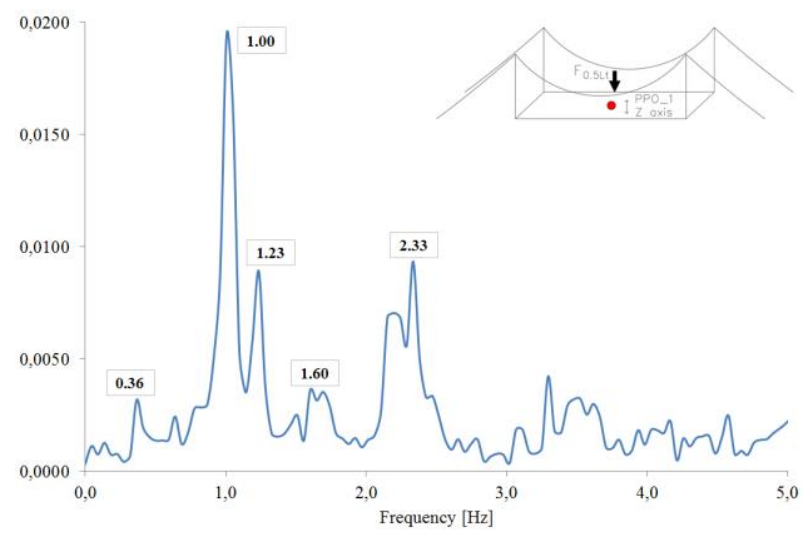

Fig. 6a. Results of the FFT analysis - at the direction $z$, load case K6, point PPO_1.

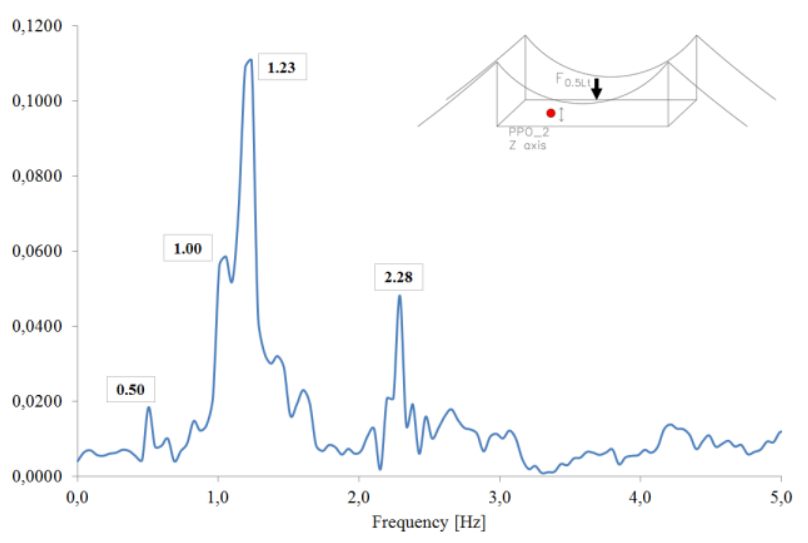

Fig. 6b. Results of the FFT analysis - at the direction $z$, load case K6, point PPO_2.



Fig. 7a. Results of the FFT analysis - at the direction $x$, load case K1, point PPO_1.

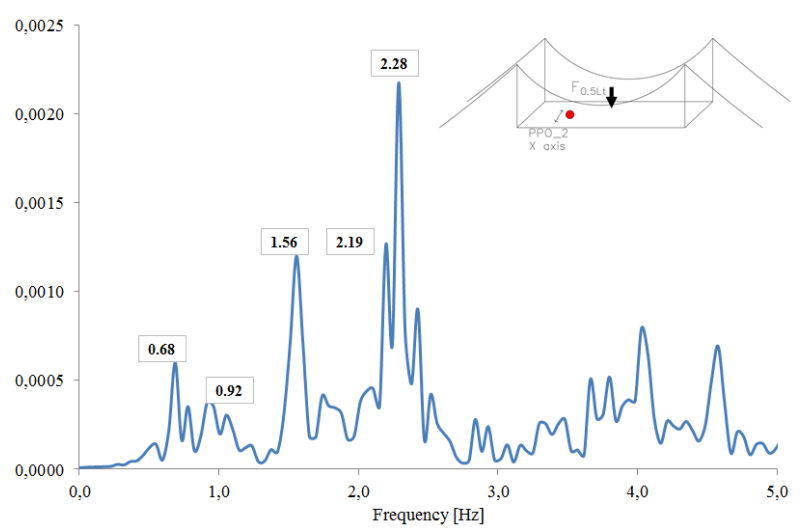

Fig. 7b. Results of the FFT analysis - at the direction $x$, load case K1, point PPO_2. 


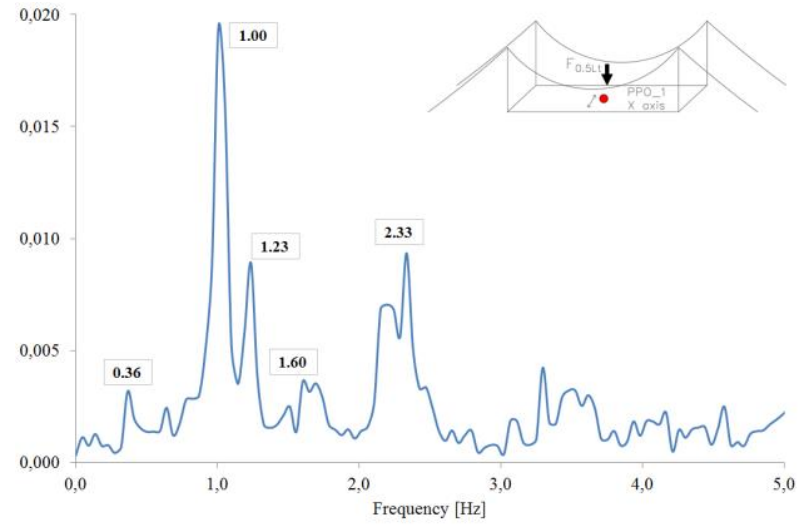

Fig. 8a. Results of the FFT analysis - at the direction $x$, load case K6, point PPO_1.

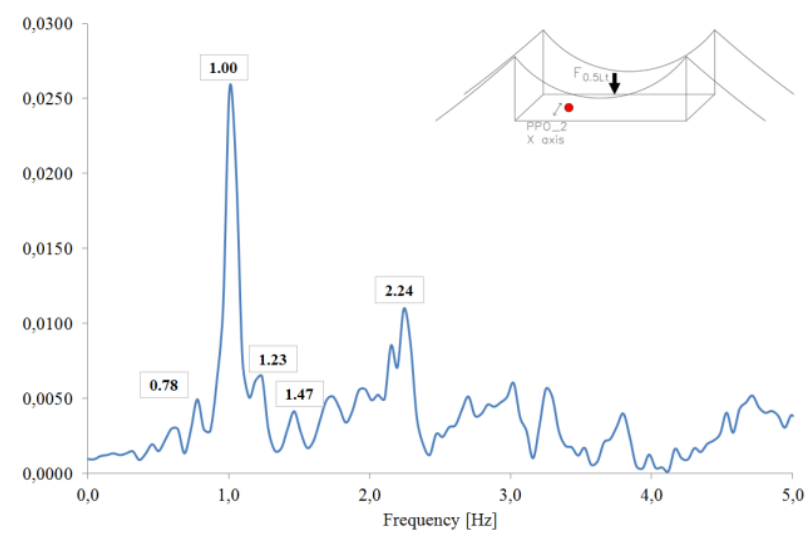

Fig. 8b. Results of the FFT analysis - at the direction $x$, load case K6, point PPO_2.

Table 4 summarizes the results of the vibration frequency values along with the description of the mode shapes. The results obtained in this way were used to verify the theoretical FE model.

\subsection{Finite Elements Analysis}

Theoretical analyzes consisted in verification of the calculated vibration frequencies of the footbridge with values obtained on the basis of in situ tests. A variable in theoretical analyzes was the value of tension in main cables. Due to the lack of information about the values of pre-stress forces during the construction of the object, the authors made an attempt to estimate these values on the basis of dynamic tests. For this purpose, a threedimensional model of the footbridge was made in the Autodesk Simulation Multiphysics program. The model was built with use of beam, truss and shell elements. The created 3D model in accordance with [4] was classified as $\left(\mathrm{e}^{1}+\mathrm{e}^{2}, \mathrm{p}^{3}\right)$. Figure 9 presents the FE model of the bridge. Below, in Table 2, the most important information on the structural elements of the footbridge is presented. The towers were set as fixed at the support without the possibility of translation nor rotation.

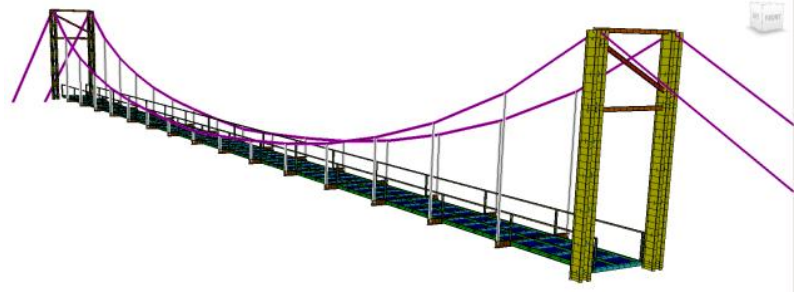

Fig. 9. FE model of the suspension footbridge.

Table 2. Description of structural elements used in FE model of the footbridge.

\begin{tabular}{|c|c|c|c|}
\hline $\begin{array}{c}\text { Structural } \\
\text { element }\end{array}$ & FE element & $\begin{array}{c}\text { Number of } \\
\text { elements }\end{array}$ & $\begin{array}{c}\text { Cross- } \\
\text { section, } \\
\text { material }\end{array}$ \\
\hline $\begin{array}{c}\text { Main lower } \\
\text { beam }\end{array}$ & beam & 384 & I 180 steel \\
\hline Cross-bar & beam & 270 & $\begin{array}{c}\text { C } 240 \\
\text { steel }\end{array}$ \\
\hline Deck & shell & 1024 & wood \\
\hline Cables & $\begin{array}{c}\text { truss } \\
\text { (nonlinear) }\end{array}$ & 560 & $\begin{array}{c}\varnothing 70 \mathrm{~mm} \\
\text { steel }\end{array}$ \\
\hline Hangers & $\begin{array}{c}\text { truss } \\
\text { (nonlinear) }\end{array}$ & 30 & $\begin{array}{c}\varnothing 20 \mathrm{~mm} \\
\text { steel }\end{array}$ \\
\hline Tower & Beam & 290 & I 450 steel \\
\hline
\end{tabular}

On the basis of the inventory, the cables were defined as braided steel ropes, for which the elastic modulus $E$ is $165 \mathrm{GPa}$. The value of the Young's modulus for girders and crossbars was $200 \mathrm{GPa}$. Two types of analyzes were carried out: static (Static Stress with Nonlinear Material Models) and modal (Natural Frequency with Nonlinear Material Models). In the created model, it was necessary to perform the division of main cables because of the presence of hangers used to suspend the deck to the main cables. Truss elements cannot be divided in analyzes in the linear range because the system becomes geometrically unstable. Such division and introduction of pre-stretch forces to cables is only possible in the case of non-linear analyzes. On the basis of the static analysis, the value of the deflection in the middle of the span was verified. The modal analysis was used to verify the received theoretical mode shapes and natural frequencies of the system. With such assumptions, eleven computational situations were analyzed and, on this basis, the evaluation of the pre-tension forces was made. Various strain values were applied to the cables according to the formula:

$$
\varepsilon=\sigma / E
$$

where :

$\sigma-$ stress $[\mathrm{MPa}]$,

$E$-Young's modulus [GPa],

$\varepsilon-$ strain $[\mathrm{m} / \mathrm{m}]$.

The values of stresses in the cables were selected in such a way that the span deflection in the middle caused by the tension forces and the dead weight resulted in positive values (upwards). Twenty mode shapes and natural frequencies of vibrations were obtained in the modal analysis. From the analyzes, it was found out that vertical flexible forms were obtained in the case of 
modes no. 1, 2, 6, 7, 12, 15 and 20, horizontal (including torsional) - no. $3,10,11,13$ and 14. Other modes show forms of cables and hangers vibration. Exemplary natural mode shapes of vibrations of the footbridge are shown in Figs 10-12, and the obtained results for vertical flexural and torsional mode shapes are summarized in Table 3.

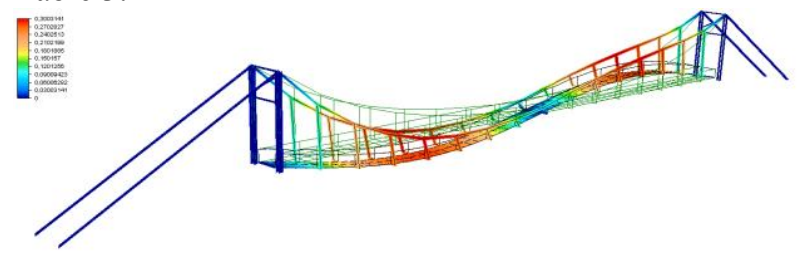

Fig. 10. First mode shape - flexural vertical,

$f_{1}=0.64 \mathrm{~Hz}, \varepsilon=0.00121 \mathrm{~m} / \mathrm{m}$.



Fig.11. Second mode shape - flexural vertical, $f_{2}=0.71 \mathrm{~Hz}, \varepsilon=0.00121 \mathrm{~m} / \mathrm{m}$



Fig. 12. Third mode shape - flexural horizontal, $f_{3}=0.92 \mathrm{~Hz}, \varepsilon=0.00121 \mathrm{~m} / \mathrm{m}$.

The deflections in the middle of the span for each analytical case can be found in the last column in Table 3.
Table 3. Analytical cases - results of calculations.

\begin{tabular}{|c|c|c|c|c|c|c|c|c|c|c|c|}
\hline 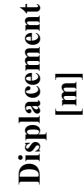 & $\begin{array}{l}\infty \\
\text { On } \\
\text { ?ִ }\end{array}$ & $\frac{⿱}{\stackrel{7}{?}}$ & 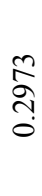 & 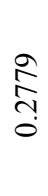 & $\begin{array}{l}\widetilde{\sigma} \\
\\
0\end{array}$ & $\begin{array}{l}\infty \\
\text { } \\
\text { ஸे }\end{array}$ & $\frac{\stackrel{n}{a}}{\stackrel{\sim}{0}}$ & $\begin{array}{l}\mathscr{\infty} \\
\stackrel{0}{0}\end{array}$ & $\begin{array}{l}\sqrt{2} \\
\stackrel{0}{0}\end{array}$ & $\begin{array}{l}0 \\
i n \\
\\
0\end{array}$ & $\begin{array}{l}\stackrel{0}{\Im} \\
\stackrel{0}{0}\end{array}$ \\
\hline$\underbrace{ \pm}$ & 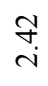 & $\stackrel{n}{\sim}$ & $\stackrel{\overbrace{}}{\sim}$ & $\vec{n}$ & 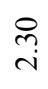 & 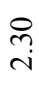 & तે & $\stackrel{\infty}{\sim}$ & $\begin{array}{l}\stackrel{\infty}{N} \\
\sim\end{array}$ & 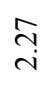 & $\stackrel{\circ}{\stackrel{0}{i}}$ \\
\hline$\Xi$ & $\stackrel{n}{n}$ & $\stackrel{\sim}{\sim}$ & $\begin{array}{c}\stackrel{\sim}{\sim} \\
\text { i }\end{array}$ & $\stackrel{\bar{c}}{i}$ & $\underset{i}{\Delta}$ & $\stackrel{m}{i}$ & $\vec{c}$ & $\underset{\mathrm{i}}{\stackrel{\mathrm{O}}{2}}$ & $\begin{array}{l}\infty \\
\stackrel{0}{i} \\
\text { in }\end{array}$ & $\begin{array}{l}\stackrel{\circ}{ } \\
\text { i }\end{array}$ & $\begin{array}{l}\stackrel{n}{0} \\
\text { in }\end{array}$ \\
\hline$\leftarrow$ & ro & $\stackrel{\mathscr{P}}{\stackrel{f}{-}}$ & ले & $\stackrel{n}{\dddot{n}}$ & $\stackrel{\sim}{\sim}$ & $\stackrel{\infty}{\stackrel{\sim}{\sim}}$ & $\underset{-}{\stackrel{+}{+}}$ & ণ্ & $\begin{array}{l}0 \\
= \\
=\end{array}$ & $=$ & $\hat{o}$ \\
\hline$\infty$ & & $\stackrel{\text { o }}{\circ}$ & 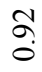 & & & హ̆ & ô & مু & $\begin{array}{l}8 \\
\circ\end{array}$ & $\begin{array}{l}+ \\
\dot{0}\end{array}$ & $\stackrel{\infty}{\stackrel{\infty}{0}}$ \\
\hline$N$ & $\stackrel{9}{0}$ & $\stackrel{\infty}{\stackrel{\infty}{0}}$ & $\stackrel{?}{\stackrel{0}{0}}$ & $\underset{0}{\stackrel{0}{0}}$ & $\stackrel{n}{0}$ & $\overrightarrow{0}$ & $\stackrel{8}{0}$ & $\stackrel{\sigma}{0}$ & $\begin{array}{l}n \\
0 \\
0\end{array}$ & $\begin{array}{l}\hat{b} \\
0\end{array}$ & $\stackrel{8}{8}$ \\
\hline 5 & $\underset{0}{\stackrel{t}{0}}$ & $\stackrel{N}{0}$ & $\stackrel{?}{\stackrel{0}{0}}$ & $\begin{array}{l}\infty \\
0 \\
0\end{array}$ & $\begin{array}{l}0 \\
0 \\
0\end{array}$ & $\underset{0}{\mathbb{0}}$ & రై & $\stackrel{8}{\circ}$ & $\begin{array}{l}\infty \\
n \\
0\end{array}$ & 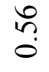 & $\tilde{n}$ \\
\hline$\omega \underline{\underline{\Xi}}$ & $\frac{\pi}{8}$ & $\frac{0}{\frac{8}{8}}$ & $\begin{array}{l}\stackrel{\infty}{n} \\
\stackrel{0}{8} \\
0\end{array}$ & $\frac{\mathscr{n}}{8}$ & $\frac{m}{2}$ & $\begin{array}{l}\bar{N} \\
\overline{8} \\
0\end{array}$ & $\begin{array}{l}8 \\
8 \\
8 \\
0\end{array}$ & $\begin{array}{l}\hat{\sigma} \\
\stackrel{8}{8} \\
0 \\
0\end{array}$ & $\begin{array}{l}2 \\
\infty \\
8 \\
8 \\
0\end{array}$ & $\begin{array}{l}\text { న } \\
\text { } \\
8 \\
0\end{array}$ & $\begin{array}{l}\overline{8} \\
8 \\
8 \\
0\end{array}$ \\
\hline $0 \stackrel{\bar{\Xi}}{\underline{\Sigma}}$ & D & $\underset{\sim}{\infty}$ &  & $\stackrel{\stackrel{+}{\sim}}{ }$ & 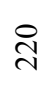 & 号 & $\stackrel{0}{\infty}$ & $\stackrel{8}{0}$ & 昌 & 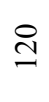 & 8 \\
\hline
\end{tabular}

In order to visualize the selection of the deflection value for which the most accurate natural frequency results were obtained, in Fig. 13 a collective graph of the strains-frequencies function is shown. Red circles represent the values obtained on the basis of the FFT analyzes of in situ accelerations.

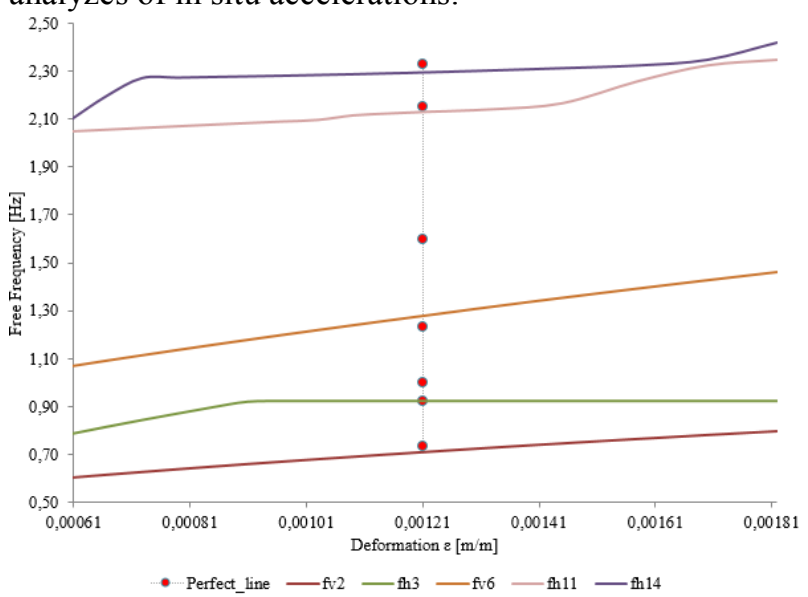

Fig. 13. Selection of strain value in relation to modal analysis and FFT results.

Analyzing the results obtained from in situ tests (measurements of accelerations and FFT analysis) and theoretical analyzes (Natural Frequency with Nonlinear Material Models) listed in Table 4 and Fig. 13, it was found that the highest accuracy of results was obtained for the initial strains in cables introduced with the values equal to $0.00121 \mathrm{~m} / \mathrm{m}$. Below, in Table 4 , the values of 
relative errors for the compared values were calculated with use of the following formula:

$$
\delta_{i}=\left(f_{i t}-f_{i r}\right) / f_{i t}
$$

where:

$f_{i t}$ and $f_{i r}$ - the values of the i-th natural frequency obtained on the basis of in situ tests and theoretical analysis.

The values for FFT for each mode shapes were selected based on all analyzes carried out from all measured acceleration courses.

Table 4. Relative error $\delta_{i}$ between the results obtained on the basis of in situ tests and theoretical analysis.

\begin{tabular}{|c|c|c|c|c|}
\hline $\begin{array}{c}\text { Mode } \\
\text { shape } \\
\boldsymbol{f}_{\boldsymbol{i}}\end{array}$ & Description & $\begin{array}{c}\text { FFT } \\
\text { analysis } \\
{[\mathbf{H z}]} \\
\boldsymbol{f}_{\text {it }}\end{array}$ & $\begin{array}{c}\text { Natural } \\
\text { Frequency } \\
{[\mathbf{H z}]} \\
\boldsymbol{f}_{\text {ir }}\end{array}$ & $\begin{array}{c}\text { Relative } \\
\text { error [\%] } \\
\boldsymbol{\delta}_{\boldsymbol{i}}\end{array}$ \\
\hline$f_{1}$ & $\begin{array}{c}\text { Flexural } \\
\text { vertical }\end{array}$ & 0.73 & 0.64 & 12.33 \\
\hline$f_{2}$ & $\begin{array}{c}\text { Flexural } \\
\text { vertical }\end{array}$ & 0.92 & 0.71 & 22.83 \\
\hline$f_{3}$ & $\begin{array}{c}\text { Flexural } \\
\text { horizontal }\end{array}$ & 1.00 & 0.92 & 8.00 \\
\hline$f_{6}$ & $\begin{array}{c}\text { Flexural } \\
\text { vertical }\end{array}$ & 1.23 & 1.28 & 4.07 \\
\hline$f_{11}$ & $\begin{array}{c}\text { Flexural } \\
\text { horizontal }\end{array}$ & 2.15 & 2.11 & 1.86 \\
\hline$f_{14}$ & $\begin{array}{c}\text { Flexural } \\
\text { horizontal }\end{array}$ & 2.33 & 2.30 & 1.29 \\
\hline
\end{tabular}

Analyzing the values presented in Table 4, one can conclude that the obtained results are satisfactory. The average relative error is in the $10 \%$ range for the analyzed natural frequencies of the structure. It should be remembered that the authors did not have any technical documentation of the analyzed object, which was the reason for some assumptions, for example regarding the parameters of some elements of the footbridge, which were difficult to access and impossible to measure using the basic measuring instruments.

\subsection{Damping parameters of the structure}

On the basis of conducted field tests and recorded values of accelerations in selected points of the structure, which were obtained from the excitations described in Table 1, an attempt was made to determine the logarithmic decrement of damping [5-7]. Reading the natural frequency of the structure from Figs 5-8 and through the use of bandpass filter (Butterworth) it was possible to determine the exponential curve (envelope) formula, which was used to calculate the value of logarithmic decrement of damping. The value was determined for three natural frequencies of the structure. Three measured acceleration courses were analyzed for each natural frequency and the results were averaged. Fig. 14 shows the course of accelerations after application of the bandpass filter at $1.60 \mathrm{~Hz}$ for the first load case K1.

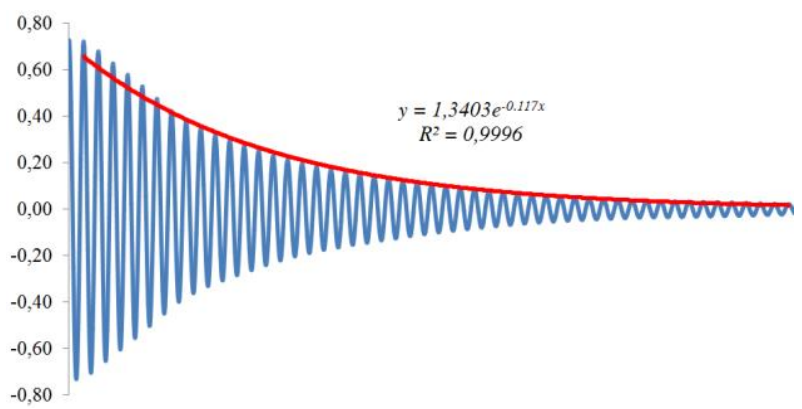

Fig. 14. Filtered course of accelerations measured at the footbridge, middle frequency of the bandpass filter $-1.60 \mathrm{~Hz}$.

The values of experimentally determined logarithmic decrement of damping were calculated on the basis of the exponential curve for various values of the free vibrations frequencies of the structure [8-10]. The following formulae were used:

$$
\begin{array}{r}
f(t)=A e^{-\beta t}, \\
\delta=\beta \mathrm{T},
\end{array}
$$

where:

$T$ - period of free vibration,

$\delta$ - logarithmic decrement of damping.

The results are presented in Table 5 and Fig. 15.

Table 5. Experimental determination of the value of logarithmic decrement of damping.

\begin{tabular}{|c|c|c|c|c|}
\hline \multirow{2}{*}{$\begin{array}{c}\text { Frequency } \\
\boldsymbol{f}[\mathrm{Hz}]\end{array}$} & \multicolumn{3}{|c|}{$\delta$} & \multirow{2}{*}{$\delta$ average } \\
\cline { 2 - 5 } & $\begin{array}{c}\text { Course } \\
\boldsymbol{1}\end{array}$ & $\begin{array}{c}\text { Course } \\
\mathbf{2}\end{array}$ & $\begin{array}{c}\text { Course } \\
\mathbf{3}\end{array}$ & \\
\hline 0.73 & 0.109 & 0.114 & 0.118 & 0.114 \\
\hline 1.23 & 0.085 & 0.089 & 0.095 & 0.090 \\
\hline 1.60 & 0.073 & 0.078 & 0.082 & 0.078 \\
\hline
\end{tabular}

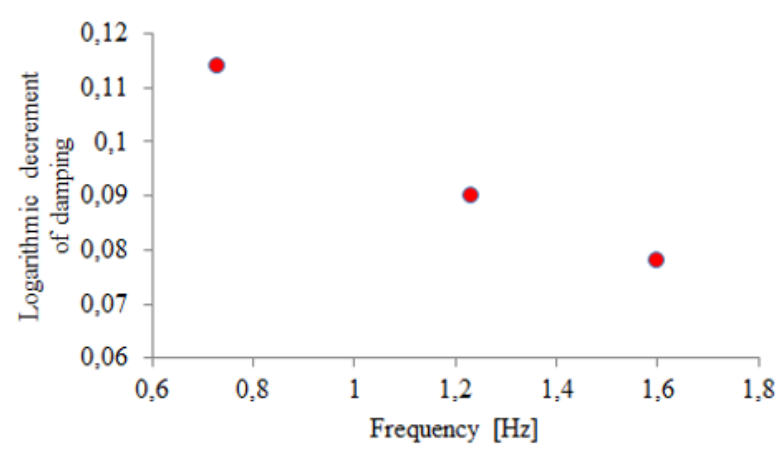

Fig. 15. Logarithmic decrement of damping in a function of frequency. 


\section{Conclusions}

Suspension structures are specific objects that cause many difficulties at the stage of performing all sorts of analyzes. Due to the very small ratio of the object width to its length, i.e. high slenderness, low lateral stiffness and small weight, the interpretation of results from the field tests is a quite difficult task. Suspension bridges, including pedestrian bridges, are treated as structures, which should be considered individually, and hence, there are no ready parameters in standards that the designer could use at the stage of verification of the adopted assumptions in the numerical model.

On the basis of in situ tests it is possible to conclude that the theoretical model presented here in this paper is in the good agreement with respect to the field tests carried out. The results obtained from the modal analysis in the non-linear range coincide with the values of the frequencies of free vibrations measured at the footbridge. The upward displacement of the span on the basis of static analysis including initial strains and dead weight seems to be a correct value. According to the authors, the experimental determination of the damping parameters of the structure, which is directly related to the concept of logarithmic decrement of damping, in the case of suspension structures is an extremely important issue.

The presented paper proposes a methodology for the determination of the values of tension forces in cables on the basis of acceleration measurements in the absence of information about the object. On the basis of data from in situ tests and modal computer analysis the initial values of tension in cables can be calculated, and directly from the acceleration time courses, the damping parameters of the structure can be determined. Thanks to the elaboration of a static scheme of the structure and having information about dynamic properties, one can simulate the behavior of the structure under the influence of loads variable in time and space. Information on the natural frequency is, among other things, necessary to determine the calculation step in dynamic analysis. Finally, the obtained data set allows to study the bearing capacity of the bridge and study the possibility of further operation of the footbridge based on computer simulations.

\section{References}

1. F. Farquharson, Aerodynamics stability of suspension bridges with special reference to the Tacoma Narrows Bridge, Parts I, III and IV., 116 (1949-1954)

2. M. Jukowski, E. Błazik-Borowa, J. Bohatkiewicz, J. Bęc, M. Hypki, 12th FIB International PhDSymposium in Civil Engineering, in press 2018

3. A. Flaga, Mosty dla pieszych., WKŁ (2011)

4. M. Jukowski, J. Bęc, E. Błazik-Borowa, AIP C.P. 1922. 150008 (2018)

5. T. Lipecki, P. Jamińska, A. Panasiuk, Logistyka, 4, 4480-4489 (2015)
6. T. Lipecki, P. Jamińska, K. Wargulak, Logistyka, 4, 4490-4498 (2015)

7. T. Lipecki, J. Bęc, K. Błaszczuk, D. Czerski, M. Kowalik, R. Selwa, Logistyka, 6 (2014)

8. P. Wielgos, Ocena skuteczności działań wielokrotnych, strojonych tlumików masowych w konstrukcjach budowlanych., Politechnika Lubelska (2011)

9. J. Bęc, M. Jukowski, Budownictwo i Architektura., 15, 177-189 (2016)

10. PN-EN 1991-2:2007, EC1 